\title{
A new species of Ardhachandra (hyphomycetes) from Vietnam
}

Mel'nik VA ${ }^{1 *}$

${ }^{1}$ Laboratory of the Systematics and Geography of Fungi, Komarov Botanical Institute, Russian Academy of Sciences, Professor Popov 2, St. Petersburg, 197376, Russia

Mel'nik VA 2012 - A new species of Ardhachandra (hyphomycetes) from Vietnam. Mycosphere 3(6), 922-924, Doi 10.5943 /mycosphere/3/6/5

A collection of a fungus belonging to the hyphomycete genus Ardhachandra was found on leaf litter of an unidentified broad-leaved tree in Vietnam and proved to be a new species, which is described as A. vietnamensis, illustrated and compared with allied species in the present paper.

Key words - Ascomycota - anamorphic fungi - new taxon - Southeast Asia

\section{Article Information}

Received 2 November 2012

Accepted 5 November 2012

Published online 19 November 2012

*Corresponding author: V.A. Mel'nik - e-mail - vadim.melnik@ mail.ru

\section{Introduction}

In 2010 and 2011, mycologists of the Komarov Botanical Institute, Russian Academy of Sciences (St. Petersburg) and Moscow State University carried out comprehensive explorations of mushrooms, aphyllophoroid basidiomycetes, discomycetes and myxomycetes in some areas of South Vietnam. The substrates of the collected samples of fungi and myxomycetes (leaf and branch litter, bark, fallen fruits, seeds, etc.) have been searched for the presence of anamorphic fungi. Some results of these studies have already been published (Mel'nik 2011, Mel'nik et al. 2012). A list of hitherto identified micromycetes includes names of about 150 species, almost all of them being hyphomycetes. Examinations of additional material from South Vietnam showed that several of the observed hyphomycetes may be new taxa. One of them, belonging to the genus Ardhachandra Subram. \& Sudha, has been examined in detail and proved to be a new species.

\section{Methods}

Fresh samples collected during the course of field trips in Vietnam were dried at room temperature. The material was examined and photographed using a Zeiss microscope, Stemi 2000CS, and Axio Imager A1 equipped with Nomarski differential interference contrast optics. Identification was carried out through comparison with current taxonomic works of fungi under consideration. The examined specimen is deposited at LE.

\section{Results}

The following description is based on fungal material recently found in Vietnam on leaf litter of an unidentified deciduous tree which proved to be a new species.

\section{Ardhachandra vietnamensis Melnik, sp. nov.}

Figs. 1-6 MycoBank, MB 801933.

Etymology - vietnamensis, referring to country where the fungus was found. 
Mycosphere Doi 10.5943/mycosphere/3/6/5

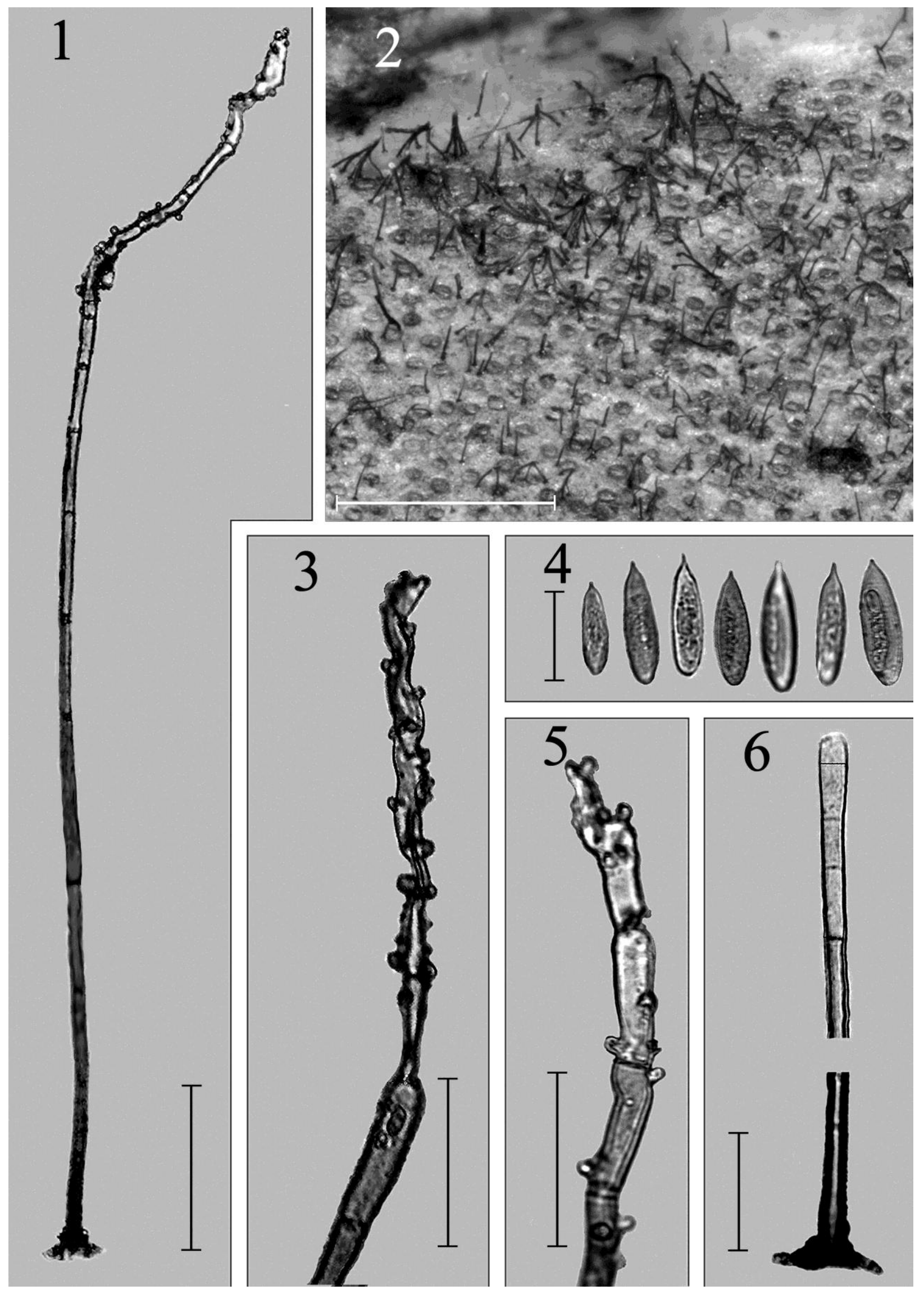

Figs 1-6 - Ardhachandra vietnamensis (ex holotype LE 261999): 1 conidiophore; 2 colony; 3, and $\mathbf{5}$ denticulate conidiogenous cells; $\mathbf{4}$ conidia in front and lateral views; $\mathbf{6}$ conidiophore with radially lobed base and conspicuously widened upper part. Bars: $1=50 \mu \mathrm{m} ; 2=500 \mu \mathrm{m} ; 3-6=25 \mu \mathrm{m}$. 
Ardhachandrae prolatofusiformis similis, sed conidiophoris distincte longioribus, 70-470 $\mu \mathrm{m}$, rhachibus flexuosis cum denticulis cardoidibus (subcylindricis) et conidiis ellipsoidibusfusiformibus, apice acuminato, basi rotundato, 23-35 $\times 8-10.2 \mu \mathrm{m}$, applanatis, lateraliter tantummodo 6-7 $\mu \mathrm{m}$ latis.

Colonies on the upper surface of leaf lamina, villous, effuse, dark brown. Conidiophores abundant, evenly scattered, solitary, macronematous, mononematous, with radially lobed base, 22-25 $\mu \mathrm{m}$ diam., septate (distance between septa 22-30 $\mu \mathrm{m}$ ), not branched, straight, smooth, pale brown to olivaceousbrown, 70-470 $\mu \mathrm{m}$ long (including conidiogenous cells), 4-5 $\mu \mathrm{m}$ wide in the middle, 6.5 $\mu \mathrm{m}$ just above the radially lobed base, up to 6 $\mu \mathrm{m}$ in upper part just beneath the denticulate conidiogenous cells. Conidiogenous cells integrated, terminal, later becoming intercalary, sympodially proliferating, cylindrical, 26-110 $\mu \mathrm{m}$ long,, rachis flexuous, with short peg-like (subcylindrical), perpendicular denticles, 2-3 $\mu \mathrm{m}$ diam., apex truncate. Conidia formed singly, smooth, pale brownish, asep-tate, with conspicuous germ slit, in front view ellipsoidfusiform with rounded base and acuminate apex (often abruptly attenuated), symmetical, 23-35 $\mu \mathrm{m} \times 8-10.2 \mu \mathrm{m}$, somewhat applanate, in lateral view narrowly fusiform, 6-7 $\mu \mathrm{m}$ wide. Teleomorph unknown.

Material examined - VIETNAM, Lam Dong Prov., Lac Duong Distr., Bidoup-Nui Ba Nature Reserve, Hòn Giao Mt., on leaf litter of a non-identified deciduous tree, 28 June 2010, E. Popov (LE 261999, holotype; HAL 2408 F, isotype).

\section{Discussion}

According to Seifert et al. (2011), the genus Ardhachandra Subram. \& Sudha comprises four species on leaf litter of broad-leaved trees in Africa, Asia and South America. Onofri \& Castagnola (1983) considered Ardhachandra a synonym of Rhinocladiella Nannf. Chen \& Tzean (1995), disagreeing with the latter opinion, described the new species $A$. prolatofusiformes J.L. Chen \& Tzean. The latter species resembles the fungus recently found in Vietnam, but differs in having shorter conidiophores (54.3-409 $\mu \mathrm{m})$, with almost uniform width beneath the flexuous denticulate rachis. In addition, the denticles of the rachis are more or less conical (Chen \& Tzean 1995: 364, Fig. 1), and the conidia are in front view oblong-fusiform, asymmetrical, guttulate, 19.4-33.2 × 5.4-8.5 $\mu \mathrm{m}$, smooth or finely verruculose. All other species of Ardhachandra are morphologically quite distinct from the Vietnamese specimen. Due to the discussed obvious differences between $A$. prolatofusiformes and the Vietnamese collection, the latter undoubtedly represents a different, probably tropical new species, described in this paper as A. vietnamenisis.

The present examinations have been carried out within the frame of a Research Program of the Russian-Vietnamese Tropical Research and Technological Center.

\section{Acknowledgements}

Evgenij Popov, St. Petersburg, Russia is thanked for providing fungal collections from South Vietnam and Uwe Braun, Halle (Saale), Germany for valuable comments and corrections of the manuscript.

\section{References}

Chen JL, Tzean SS. 1995 - A new species of Ardhachandra from Taiwan. Mycological Research 99, 364-366.

Mel'nik VA. 2011 - Anamorphic fungi of Vietnam. I. Mikologiya i Fitopatologiya 45, 323-331 [in Russian].

Mel'nik VA, Novozhilov YuK, Popov ES, Alexandrova AV. 2012 - Anamorphic fungi of Vietnam. II. Mikologiya i Fitopatologiya 46, 323-331 [in Russian].

Onofri S, Castagnola M. 1983 - The genera Ardhachandra and Rhinocladiella, their synonymy. Mycotaxon 18, 337-343.

Seifert K, Morgan-Jones G, Gams W, Kendrick B. 2011 - The Genera of Hyphomycetes. CBS Biodiversity Series 9, 1-997. 